\title{
The 19th Century European Missionaries and the Fight Against Malaria in Africa
}

\author{
Diara, Benjamin C. \\ Department Of Religion And Cultural Studies, \\ University Of Nigeria, Nsukka- Nigeria \\ Diara, Johnson C. \\ Sudan United Hospital Onuenyim \\ Abakaliki, Ebonyi State, Nigeria \\ Nche George Christian \\ Department Of Religion And Cultural Studies \\ University Of Nigeria, Nsukka- Nigeria
}

\section{Doi:10.5901/mjss.2013.v4n16p89}

\begin{abstract}
Malaria once turned Africa into the "missionaries' graveyard" as many European missionary personnel and families perished planting the Gospel in the Continent in the 19th century. The situation, however, is not completely different today in many rural African communities. The purpose of this research is to present a social challenge to the present day Christian missionaries in Africa by describing the landmark achievement of the 19th century missionaries in the fight against mosquito plague in Africa, namely their introduction of the first ever drug for malaria treatment in the continent. Central and West Africa are used as a case for this study. This research applied descriptive analysis to the health and life situation that faced the early European missionaries as they laboured to evangelize the people of Africa.
\end{abstract}

Keywords: missionaries, malaria, mosquito plaque, health challenges, quinine.

\section{Introduction}

The lethal effect of malaria on human life and health in Africa has been colossal. To say that malaria is one of the most disturbing and dangerous illness suffered in Africa is simply stating the fact. Nevertheless, medical advances have made it that today's missionaries to Africa, a region that was described as the missionaries' graveyard in the $19^{\text {th }}$ century because of the wide-spread deadly effects of malaria on missionaries, no longer see themselves as having been sent to certain death.

Malaria and many other diseases of public health importance such as filariasis, dengue fever, yellow fever and Western Nile virus are mosquito borne diseases. Of these diseases, malaria was the greatest bane of missionary work in Africa in the 19th century. Missionaries such as David Livingstone, Mary Slessor and a host of others died in Africa in that era directly or indirectly as a result of malaria. In those early years, missionaries persisted and persevered in their commitment to convert Africa amidst malaria plague. Rowland Bingham (www.wisegeek.com) a missionary to Nigeria vowed: "I will open Africa to the Gospel or die trying". This type of devotion to the cause of the Gospel is obviously rare today in Africa. Why is it that with all the modern scientific and technological advantages, today's missionaries still lag far behind the 19th century 
missionaries in terms of actual effectiveness.

This paper is the report of a study carried out with the objective of investigating the secret of the dogged commitment of the $19^{\text {th }}$ century missionaries to the conversion of Africa which made them succeed in planting Christianity in Africa in the era of the Continent's dark socio-economic ages amidst uncontrolled malaria attack on human life among other factors. In the early period, it was malaria attack that threatened to hinder Christian missionary enterprises in Africa as many Europeans who may have volunteered to come to Africa as missionaries could not show up for fear of death. Today, in addition to malaria threat, there are other factors of fear such as social hostility, religious intolerance, official prohibition and persecution, as the case may be, in various parts of Africa. Yet malaria plague on natives as well as missionaries has not completely abated in Africa as malaria mosquitoes still abound in the continent.

The study scaled from the analysis of the early missionary attitude to that of the challenges before the present day missionaries in connection with the situation of social threats to life including such that malaria still poses in many parts of Africa today. It is hoped that this paper will spur the present day missionaries in Africa on to a more committed and effective missionary vocation. Out of their dogged commitment to missionary work amidst the health challenges before them in Africa the early European missionaries were able to successfully grapple with the problem of malaria attacks in the continent as far back as the 19th and early part of the $20^{\text {th }}$ century. The challenge before today's missionaries in the continent is dual dimensional: firstly, they have the challenge to develop the attitude of persistence and perseverance in their mission fields like the early missionaries and secondly, they are faced with the task of contributing their own quota to the efforts towards total eradication of malaria disease in the African continent.

\section{Malaria: A Deadly Disease}

Malaria is a mosquito-borne disease. Mosquito injects the disease into the human health system by feeding on the fluid of man, i.e. blood. Its mandible and maxillae cut the skin and make a tunnel through the tissue to the blood stream. The labrum and hypopharynx pass into the blood vessels while labium stays on the skin. The hypopharynx injects saliva into the blood; this is to prevent the blood from clotting. It also injects plasmodium causing malaria, the blood is then sucked into the food canal called pharynx. The plasmodium injected into the blood is carried to the blood stream. It fights against the white blood cells (leucocytes) destroying the immune system of man. When the immune system is totally destroyed, the individual becomes prone to the havoc of malaria fever.

This can be very deadly if not properly taken care of. Serious cases of malaria cause death if not properly handled. When malaria causing bacteria is introduced into the body of man it blocks the delicate capillaries of the blood vessels. It also introduces toxins which go a long way in blocking the capillaries of the blood vessels and when this happens it leads to lethal effect. The overall effect is death if serious measure is not taken to forestall it. Where there is no direct lethal effect, the surface membrane of the blood vessels and that of the Red Blood Cells becomes sticky and tends to adhere to certain parts of the human body.

While most malaria parasites need not be fatal, the resulting bouts of fever, shivering, etc., can cause a lot of weaknesses. The plasmodium falciparium parasite however can cause serious complications including low blood sugar levels, abnormal accumulation of fluids in the lungs, spontaneous bleeding, circulatory collapse and shock.

Malaria parasites might be very fatal as when it causes much feared cerebral malaria. Malaria is highly dangerous for pregnant women and the unborn child who are likely to develop the more severe cases of malaria. Mosquito poses more threat to the health of people, especially inhabitants of Africa than other disease carriers. The World Health Organization (2008) confirms this assertion:

Over a million people die every year as a result of malaria, especially Africans. This is because the vector - Anopheles mosquito is predominant in Africa especially Sub-Saharan Africa. Although it can also be found in South-East Asia, they are much fewer. Mosquitoes are predominant in Africa because the 
environment encourages its breeding and rapid increase.

Most mosquito bites are nothing but annoying. However, in a time when there are so many deadly diseases, it is best to protect oneself the best one can to ensure that one does not become the next victim of a mosquito-malaria. The Wikipedia: the Free Encyclopedia (Fradin:1998) has the following analysis of the global effect of mosquito bites:

Mosquitoes are estimated to transmit disease to more than 700 million people annually in Africa, South America, Central America, Mexico and much of Asia with millions of resulting deaths. In Europe, Russia, Greenland, Canada, the United States, Australia, New Zealand, Japan and other temperate and developed countries, mosquito bites are now mostly an irritating nuisance; but still cause some deaths each year. Historically, before mosquito transmitted diseases were brought under control they caused tens of thousands of deaths in these countries and hundreds of thousands of infections. Mosquitoes were shown to be the method by which yellow fever and malaria were transmitted from person to person by Walter Reed, William C. Georgas and Associates in U.S. Army Medical Corps first in Cuba and then around the Panama Canal in the early 1900s. Since then other diseases have been shown to be transmitted the same way. In recent times, health researchers have sought permanent solution to the high rate of death as a result of malaria. It has however been proved that the female anopheles mosquito has very high resistance to insecticides and that the parasite, plasmodium, is also very resistant to certain drugs.

Fortunately, fewer than 100 of the world's known 2,700 mosquito species actually carry disease. But with those 100 species buzzing around with their annoying sound, there are still 100 mosquito species that human, birds, all other animals have to worry about (http://www.sciam/blog).

A malaria mosquito can cause a person to have a few different symptoms. These symptoms can start as a simple fever or body aches that eventually can lead to seizures, coma, or even death. Largely found in areas of Africa, Central America, South America, Asia, Eastern Europe, the South Pacific and Hispaniola, it seems like only a matter of time before this mosquito disease finds a large home for itself in North America. Although it is a misconception to suppose that the mosquito and HIV are somehow connected, some mosquitoes can be as deadly as HIVIAIDS especially when one comes in contact with a combination of two or more mosquito-borne diseases.

\section{Missionary Experience and the Introduction of Quinine in Africa}

The socio-economic loss that malaria caused for Africa before and during the missionary era was incalculable. The loss of lives were irreparable for those who died, both the whites and the blacks, might have been the talents that could have produced the skills and tools with which Africa would have been developed to improve their society and economy like the western world. This has been a persistent problem of Africa since the inception of mankind in the Continent. It might therefore not be wrong to claim that malaria has done more harm to Africa than HIVIAIDS which has a relatively recent history in the world. The fight against this deadly disease in Africa was thus most germane when the European missionaries came in the $19^{\text {th }}$ century.

Malaria was part of the ugly health situation that European missionaries met in Africa when they arrived. The average life expectancy of missionaries in Central Africa as a result of mosquito plague was 8 years and in West Africa 2 years. Some died within 3 months of arriving. The experiences of the missionaries at the face of the notorious malaria plague of that era can be captured by the communication of a CMS Missionary to Uganda, Alexander Macay, who expressed the single minded determination common to early missionary volunteers: "I want to remind the committee that within six months they will probably hear that one of us is dead. But... when that news comes, do not be cast down, but send someone else immediately to the vacant place" (www.wisegeek.com). Within three months one of them was dead. Within a year two more had perished. Within two years Mackay was the only one of their missionaries left alone in Uganda. He actually survived 12 years. 
It was this experience of the European missionaries that informed the need to introduce the antimalarial drug, namely quinine in Africa. Quinine was the original anti-malaria drug. It had been used for more than three centuries and until the 1930s it was the only effective agent for the treatment of malaria in Africa. Many of the later anti-malarial drugs are derivatives of the compound. It was found in the bark of the cinchona, a South American native tree, and is the only drug which over a long period of time, has remained largely effective in treating malaria. It is now only used for treating severe falciparium malaria, partly because of undesirable side effects (Lambert, 2011).

The discovery of quinine and its subsequent introduction in Africa were connected with European missionary activities. Precisely, Europe was introduced to quinine in the 1600s when the Jesuit missionaries first brought the "miracle bark" to Europe from their South American missions (www.wisegeek.com). When Europeans began to make use of the drug for the treatment of fevers associated with malaria, they discovered that it was highly effective against certain strains and Jesuit Missions soon began to rake in money from their quinine extraction operations.

From this point, missionaries going to strange lands, especially in the tropics, began to equip themselves with quinine drug. Initially, the European missionaries came to Africa with neither anti-malarial drug nor mosquito nets. With time these facilities were introduced into Africa, but in some cases, even when the missionaries had the facilities they were not used to making use of them either for too much commitment or in sympathy with the natives who did not have, hence the quantity they had could not go round those who needed it. For instance, Mary Slessor of the Church of Scotland Mission which founded the Presbyterian Church in Nigeria refused to sleep under her mosquito nets because of her commitment to reaching out to the natives in their various villages. Often she did not find a place to sleep and had to sleep on the ground (Agha: 2011:18f).

Subsequently, following the discovery of quinine, health researchers have sought permanent solution to the high rate of death as a result of malaria. Consequently, more anti-malarial drugs have been produced. Such drugs include alebrin, mefloquine, halofantrin, malorone, artemisinin, Darapin, Paladrine, nivaquine, chloroquine, resochin etc. The outcome of this scientific exploit, namely, the discovery of quinine and the subsequent medical findings has contributed in changing the story of Africa as the missionaries' grave. Nevertheless, much is yet to be done to completely tackle the situation of malaria plague in Africa.

\section{The Challenge Before Today's Missionaries in Africa}

The challenge before the present day missionaries in Africa in the context of the subject matter of this research is twofold. Firstly, the present day missionaries are challenged to develop the attitude of persistence and perseverance in their mission fields like the $19^{\text {th }}$ century missionaries. And secondly, they are to contribute their own quota to the efforts towards total eradication of malaria disease in the continent in such conventional ways that the governments, non-governmental agencies, families and individuals have been involved.

In parts of Africa today, to preach the gospel attracts serious opposition by religious fanatics, especially Islamic fundamentalists. In some, there may be no open or frontal opposition but the society may be generally hostile to gospel preachers. The governing authorities of some African countries also make the matter worse by forbidding the work of evangelization in their countries and usually to go against such legislations translates to official persecution and prosecution and sometimes even execution for the missionaries. In the midst of such situations, the missionary is faced with very challenging situation for his work. The missionaries are expected to live up to the challenge by committing their lives to the cause of their work. A missionary is a witness for Christ and the word for witness here is Gk. marture which also connotes a martyr (Diara, 2009).

Amidst all the challenging social situations that Christian missionaries face in Africa today, mosquito still constitutes a deadly army militating against missionary work in some parts of Africa. For instance, in 
Kenya, mosquito menace constitutes a serious challenge to missionaries, particularly in places like Kitale, Western Kenya, Kiberia slums in Nairobi and Mombasa in the Coast Province. Also in Nigeria, Nsukka in Enugu State in particular, where the author of this article, who incidentally is a missionary, currently lives appears to be the worst hit. The situation causes the inhabitants untold hardship as the activities of mosquitoes the number of which keeps on increasing on daily basis, constitute a nightmare to them, especially when there is no insecticide to apply in the night.

Thus mosquito still poses great health challenges to today's missionaries in Africa. Missionaries living in houses suffering from mosquito attacks may suffer mental disorders as a result of distraction from their bites and noises. At night, when they are meant to rest after a hectic day's activities, the disturbance coming from mosquito can well cause mental problems in addition to physical ill-health.

Ironically, the cost of preventing malaria by periodic drugs and purchase of insecticides used for killing mosquitoes as well as money needed for the destruction of the breeding sites of mosquito is too exorbitant for the poor African missionaries. Treated mosquito nets and other chemical requirements for fighting mosquito are very expensive and cannot be afforded by all the missionaries in the mosquito plagued areas of Africa. Thus, the activities of mosquito and the effects of their bites cause a very big socio-economic problem to the missionaries as well as the natives of Africa.

To this effect, today's missionaries in Africa, especially those in rural communities should not only preach spiritual gospel. In addition, they have to encourage the people both by teaching and practical examples to take proactive and preventive action against mosquito. This is part of the church's call to tend and care for God's flock whose lives are being threatened in one way or the other. Therefore, the missionaries in addition to preaching the biblical gospel should also be engaged in social gospel of which a vital aspect includes teaching the people about the health and economic importance of fighting against mosquito.

Christian Churches in Africa have a partnership role to play in the efforts of the governments to combat malaria and other mosquito plagues in the Continent. Missionaries should therefore participate actively in their host countries' programmes of war against malaria. Mosquito is the only known vector of malaria and therefore eradicating it in Africa means eradicating a deadly disease from the continent. This should not be left for the government and non-governmental organizations only.

Missionaries in other African countries should take a clue from what missionaries in Kenya are doing. As malaria continues to hit the Kenyan people, the Christian missionaries in the Country are involved in prevention measures against the dreadful disease in a significant way. In a recent interview, Joe Healey (www.wisegeek.com) reports that "the Maryknoll missionaries are currently giving highly effective mosquito nets to poor families in Kitale, Western Kenya, Kiberia slums in Nairobi and Mombasa in the Coast Province".

For the fact that the treated mosquito nets are not widely and adequately distributed, many families in Africa do not have even a single net with the result that most people in Africa are exposed to the bites of mosquito which result in general weakening of human cells, tissues, organs and systems of the body, thereby causing malfunctioning of the body. In such a health state, a missionary will not be able to perform well thereby leading to low missionary progress. That is why today's missionaries, like their forebears of the $19^{\text {th }}$ and $20^{\text {th }}$ centuries, should rise up to the challenge of eradicating mosquito in their environments by any available means.

Missionaries in Africa should be able to teach the people living in mosquito plagued areas to fill their compound with sand and avoid easily water-logged, swampy, damp areas and stagnant water in empty vessels and nearby gutters in order to destroy mosquito larva and pupa. They should sprinkle on the surfaces of stagnant waters kerosene mixed with pyrethrum. This leads to eutrophication (depletion in the level of oxygen in the stagnant water). This makes respiration impossible and the wriggler and pupa die off (Fradin, 1998).

Also, the introduction of organisms which are predators of the larva and pupa of mosquito into empty vessels and gutters containing stagnant water is an encouraged measure to kill off the larva and pupa. Such 
organisms include Alestes and Tilapia. This is a biological method of controlling malaria plague. Pouring paris green on water surface, and other chemicals quickly destroy the larva and pupa of mosquitoes.

When one goes for anti-mosquito products, one should be sure to choose the one that will be the safest and most convenient. For instance, mosquito nets are helpful, but one will only be safe while one is under the net. For constant protection, it may be best to use a product like a Mega-Catch Mosquito Trap so one and one's family can be protected from mosquito bites and mosquito diseases all day and night. Some of the best mosquito traps and methods include: DEET spray, Mosquito nets, Citronella candles, Garlic repellant and Mega-Catch Mosquito Traps (Fradin: 1998). All of these products will keep one and one's family safe.

To combat the plasmodium parasite when already injected into the body system, the plasmodium should be destroyed in time to prevent malaria fever. The use of preventive drugs is to destroy the plasmodium when it has not yet caused the illness. Drugs such as Darapin and Paladrine are preventive drugs. Curative drugs such as nivaquine, chloroquine, and resochin will help cure the illness.

To ensure that their health is not attacked by malaria, people who live or and work in swampy and riverside areas should wear recommended mosquito repellant clothes or use chemicals such as dimethyphthalate to rub the body. They should clear nearby bushes and remove vessels which can contain stagnant water and take proper care of the gutters and surroundings. Missionary personnel and their families should be involved in this society friendly exercise as an important aspect of their vocation to better the living condition of the inhabitants of their mission fields.

\section{Recommendations}

From the foregoing a number of significant findings have been made on the basis of which the following recommendations have been proffered for possible solution to the problem of mosquito plagues and the resultant spread of the deadly malaria disease in the Continent:

- The Need for holistic war against mosquito in Africa: The World Health Organization has posited that the use of treated mosquito nets is the way out of the mosquito associated problems of man. It is said that people who sleep under treated mosquito net as recommended by health officials will never suffer as a result of mosquito bites. But the bites which are suffered at the early hours of the night before bed time cannot be prevented with mosquito nets. It is therefore imperative for African governments and non-governmental bodies to embark on a holistic war against mosquito with a target to completely eradicate the insect from the continent.

- Missionaries should know the various methods of fighting malaria: As can be seen above, there are various ways of fighting malaria attack ranging from physical destruction of mosquito with its lava and pupa to the use of biological and chemical measures. It is highly recommended that the present day missionaries in Africa should be versed in the various methods of preventing malaria, the most effective of which is direct killing of mosquitoes through chemical and physical means. The missionaries cannot give what they do not have; they cannot teach the people how to prevent malaria if they themselves are not fully informed about the methods.

- Health seminars to be organized for the People: It is necessary that missionaries in Africa especially those working in mosquito plagued areas should organize health seminars for the people. One of the lessons to be taught the people during such seminars should be how to effectively fight against mosquito thereby preventing malaria attack in their families.

- Churches to assist the Governments in provision of facilities: Most of the measures for tackling malaria plagues are not within the reach of many families in Africa hence the church should go the extra mile of assisting the government in the task of providing the facilities needed for eradicating mosquito from human environments. This will make for conducive, healthy and less risky missionary enterprise for the $21^{\text {st }}$ century church in Africa. This is the aspect of missionary work that is referred to as activism as it involves active participation in social welfare and development. 


\section{Conclusion}

It is persistence and perseverance that fulfill the Great Commission. In spite of the deadly attacks of malaria on the early missionaries, they persisted and persevered in their determination to win the African for Christ. This was the secret of the success story of Christianity in Africa in the $19^{\text {th }}$ and $20^{\text {th }}$ centuries, especially in the West and Central Africa. The early missionaries were so tenacious in their task of evangelization but unfortunately modern missionaries lack the tenacity. Although today's missionaries do not lack the tools, inventions are poor substitutes to tenacity. Computers and other technological gadgets cannot make up for lack of commitment. We have lots of missionary plans and programmes, but we lack persistence and commitment to the task of dealing with threats to human health and life in our society.

Thus, the death tolls from malaria and all the diseases of mosquito are still a great burden to the African region. In other words, mosquito bites still pose a serious challenge to human health and life in many, if not all, African countries. The church should therefore not sit down and watch the health and lives of her members being ravaged by malaria. Both the governments and non-governmental bodies, including Christian denominations and societies, in African countries should rise up to the great task of total eradication of malaria from the African society.

Successful combating of malaria plague has to be integrated, involving environmental, biological, mechanical and chemical methods of mosquito eradication which already enjoy resounding success in many Western countries, parts of Asian Continent and very few African countries excluding Nigeria and the rest of the West African countries. Christian Churches and present day missionaries in Africa are therefore called upon to assist in this direction.

\section{References}

Agha, A.U. (2011), The Earliest Beginnings of Christian Missions in Nigeria and the Militating Effects of African Social Institutions (1800-1900), Unpublished Material.

Allen, R.F. (1971), Socio-Cultural Dynamics: An Introduction to Social Change, New York: Macmillan Publishing Company.

Chukwuezi, B. (2000), Issues in Community Development, Nsukka: Mike Social Press.

Crosby, M.C. (2005), The American Plague, New York: Berkley Books.

Denisoff, R.S. and Wahrman, R. (1975), An Introduction to Sociology, London: Collier Macmillan Publishers.

Diara, B.C. (2009), Saint Paul: The Missionary Par Excellence, Nsukka: Nsukka Diocesan Press

Egwu, E.U. (1995), "The Psycho-Dynamics of Corruption in Nigeria" in Onuoha, J.I. and Ozioko, eds., Contemporary Issues in Social Sciences

Fradin, M.S. (1998), "Mosquitoes and Mosquito Repellants: A Clinician's Guide" in Annals of Internal Medicine, 1 June 1998, 128: 931-940.

Giddens, A. (1981), "Power, Property and the State" in A Contemporary Critique of Historical Materialism, Berkley: University of California Press.

Green, A. (1975), Social Problems: Arena of Conflicts, New York: McGraw-Hill.

Idodo-umeh, G. (1996), College Biology, Benin City: Idodo-Umeh Publishers Limited.

Igbo, E.U.M. and Anugwom, E.E. (2002), Social Change and Social Problems: A Nigerian Perspective, Nsukka: AP Express Publishers.

Jailee, P. (1960), The Third World in World Economy (Translated by Merry Klopper), New York: Monthly Review Press.

Lambert, P.H. (2003), "Malaria, Past and Present", Nobelprize.org.16 Dec 2011 http://www.nobelprize.org/education /medicine/malaria/readmore/treatment.html

Locke, S.F. (2008), "Bug vs Bug: How do mosquitoes survive deadly viruses unscathed?" http://www.sciam.com/blog/60second-science

Mccullough, D. (1977), The Path Between the Seas: The Creation of the Panama Canal 1870-1914, Simon and Shuster.

Nwala, T.U. (1997), Nigeria: Paths to Unity and Stability, Nsukka: Niger Books and Publishing Company.

Oduaran, A.B. (1993), "People's Participation and Access to Development Resources and Services", Nigeria Journal of Administration Sciences, Vol. 4 No.1 
Okolo, C.B. (1993), African Social and Political Philosophy: Selected Essays, Nsukka: Fulladu Publishing Company

Omoruyi, F.E.O. (2001), The Dynamics of Community Development: The Nigerian Approach, Benin City: New Era Publications.

Rodney, W. (1972), How Europe Underdeveloped Africa, Abuja: Panaf Publishing Inc.

Rostow, W.W. (1960), The Stages of Economic Growth: A Non-Communist Manifesto, Cambridge: Cambridge University Press.

Ryan, B.F. (1969), Social and Cultural Change, New York: The Ronald Press

Wallerstein, I. (1987), "World-Systems Analysis", in A. Giddens and J. Turner (eds.) Social Theory Today, Stanford: Stanford University Press.

World Bank: Country News, Feb.15, 2010. 